\title{
HEAT LOCALIZATION IN THE MEDIUM IN BLOW-UP REGIME
}

\author{
(D)Nikolay G. Kokodiii ${ }^{\mathrm{a}, \mathrm{b}, *}$, (D)Stanislav V. Pogorelov ${ }^{\mathrm{b}}$ \\ ${ }^{a}$ V.N. Karazin Kharkiv National University, Kharkiv, Ukraine \\ ${ }^{b}$ National University of Pharmacy, Kharkiv, Ukraine \\ *Corresponding Author: kokodiyng@gmail.com, phone: +380-50-637-54-04 \\ Received July 15, 2020; revised September 21, 2020; accepted October 14, 2020
}

The existence of the effect of heat metastable localization in the medium in the blow-up heating regime was experimentally proved. This is the regime in which the heating energy for a finite period of time tends to infinity. Previous theoretical studies have shown that in this case some regions, inside of which the temperature increases, may arise, while their size remains constant or decreases with time (heat localization regions). These regions exist as long as there is some energy input from the outside. An installation for the experimental study of the thermal blow-up regimes in a solid was developed. The object of research was an aluminum rod with a heater at its end. The temperature distribution along the rod was measured with thermocouples. The temperature of the rod end could vary according to the given law. Calibration of the installation was performed. The sensitivity of thermocouples was determined. The inertia of the heating and cooling process was estimated. The mathematical description of the thermal processes, occurring during the experiment, was made. The nonlinear equation of heat conduction for the rod was solved, with the heat exchange with the environment by convection and radiation taken into account. The thermal regime at the boundary, which is necessary to create the thermal structures, was determined. The temperature distribution in the rod in the blow-up regime and non-blow-up regime was measured. In the blow-up regime the heat front (the coordinate of the point with the temperature equal to half the maximum temperature) initially shifts from the heat source, and then in the opposite direction, and the size of the area under heating decreases. In the non-blow-up regime the size of the heated region increases all the time. The predicted effect was supposed to be used in installations for thermonuclear fusion where the target was heated by laser radiation pulses of a special shape. This effect can also be used for localized heating in cutting and welding, when the adjacent regions are not to get very hot, and in other similar situations.

KEY WORDS: heating, blow-up regime, heat structures, experiment

The blow-up regime is a system development regime, in which one or several parameters tend to infinity within a finite period of time. Real physical quantities, of course, do not reach infinite values, but they can increase sharply in a short time. The analysis of the blow-up regime shows that unbounded solutions manifest their characteristic properties before the infinite values are reached. This allows estimating the parameters of such a regime at the moments of time close to "disastrous".

The blow-up regimes exist both in physics and in the animate nature.

1. In the special theory of relativity it is indicated, that the increase in the particle mass, as the speed of its movement approaches the speed of light, occurs according to the hyperbolic law, that is, in the blow-up regime.

2. It is stated, that the population of the Earth is currently growing in the blow-up regime [1]. The investigations of the mathematical model of this process and comparison with graphs, plotted on the basis of historical data on the number of population in different epochs, were carried out in [2, 3]. They show the validity of this model.

3. The growth in the number of scientific publications and the growth in the number of research papers also take place in the blow-up regime. The articles have an autocatalytic effect. Each article facilitates writing the next one. And the more articles are published in a particular area, the easier it is to conduct subsequent researches in it.

4. There are thermal blow-up regimes. They were predicted by the team of A.A. Samarsky-S. P. Kurdyumov at the Keldysh Institute of Applied Mathematics RAS, Moscow, Russia. The theoretical studies have shown that under such regimes some new physical phenomena should arise, namely, localization of heat in certain areas of the body under heating and formation of heat structures, i.e. of regions with a high concentration of energy, which are sharply separated from the cold regions. The structures are self-sustained; they exist as long as there is an influx of energy from the external sources. This phenomenon is called "the effect of metastable heat localization" [4-7].

In these works the problem of heat propagation into a cold half-space, when the boundary was heated in the blowup regime, was solved. In the one-dimensional case, the process of heat propagation is described by the nonlinear equation of heat conduction:

$$
\frac{\partial}{\partial z}\left(a(T) \frac{\partial T}{\partial z}\right)-\frac{\partial T}{\partial t}=0
$$

where $T$ is temperature, $a(T)=k / c \rho$ is thermal diffusivity of the medium (it is emphasized that it depends on the temperature), $k$ is heat conductivity factor, $c$ is specific heat capacity, $\rho$ is the medium density.

It has been found that if the temperature at the boundary of the medium with the coefficient of thermal diffusivity, which is growing with the temperature, increases, tending to infinity at approaching the finite moment of time, then there is no heat propagation deep into the medium during the time interval when the heat is supplied. 
Let, $a(T)=a_{0} T^{\sigma}$, where $\sigma>0$, then the initial temperature of the medium is $T(z, 0)=0$.

At the boundary the temperature rises according to the law:

$$
T(0, t)=\frac{T_{0}}{\left(t_{f}-t\right)^{n}},
$$

where $t_{f}$ is the time, called in these problems as "focusing time".

There are three heating regimes:

1. At $n>1 / \sigma(H S$ - regime $)$ - the heat localization is absent. The heat propagates into the cold environment in the form of a wave with a growing half-width of the temperature front.

2. At $\mathrm{n}=1 / \sigma(S$ - regime) the problem has the analytical solution:

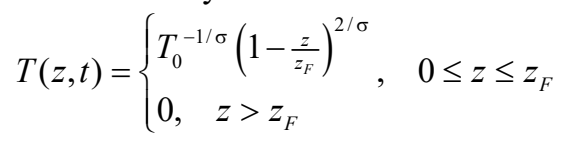

where $z_{F}$ is the depth of heating the matter by a thermal wave. The wave does not vary in time, although the amount of heat in the localization zone increases indefinitely. But the heat does not propagate further away into the medium.

3. At $n<1 / \sigma(L S-$ regime) the depth of heat penetration into the medium decreases with time, the wave front does not advance further, and the half-width of the front decreases.

Thus, the thermal effect of the boundary $S$ - regime and $L S$ - regime on the medium is localized.

In [7] the experiment conditions for the case, when the effect of heat localization could be observed, were formulated:

1. the presence of the blow-up heating regimes $S$ or $L S$, when the amount of incoming heat increases in time drastically;

2. the medium thermal diffusivity grows as the temperature increases, what increases the influx of heat into the heated region and decreases the heat transfer to the cold region.

3. during the heating period the temperature at the boundary should increase by 10-30 times.

However, in [8] it was shown that the experiment conditions may not be so stringent. The effect of heat localization can also be observed in the media with the thermal diffusivity, which does not depend on the temperature. In this case there is no strict boundary for heat localization $z_{F}$. The coordinate of this point is constantly moving upward. But the half-width of the heat front remains constant or decreases in the process of exposure to heat. The temperature difference can be considerably less - by 5-6 times.

Further works on the study of the blow-up regimes were carried out in other directions; they were mainly associated with the analyses of these regimes in the nature and in human society. The investigations were devoted to connections of the emerging phenomena with synergetics, i.e. the science explaining the formation and selforganization of structures in open systems, which are far from the thermodynamic equilibrium [9]. These works were only of theoretical character.

The exception were studies of a new physical phenomenon - the T-layer effect - the occurrence of a stable zone in the plasma placed in a magnetic field with the stable zone temperature being higher than that of the rest of plasma. The phenomenon was discovered in 1965 by a team of scientists directed by A. N. Tikhonov and A. A. Samarsky at the Institute of Applied Mathematics of the USSR Academy of Sciences. The T-layer phenomenon plays an important role in theoretical and applied plasma physics (development of MHD generators, controlled thermonuclear fusion). The Tlayer, like a piston moved by a magnetic field, allows controlling the behavior of low-temperature plasma and transforming its energy into optical radiation.

This phenomenon was experimentally investigated at the Institute of Theoretical and Applied Mechanics SB RAS (Novosibirsk) [10].

Several experimental works have appeared in recent years [11-16].

In work [16] were studied an insulator-metal transition (IMT) in vanadium dioxide films. Main features of the voltage-induced IMT in these systems can be understood within a theory of the blow-up overheating instability. In the blow-up regime, the IMT occurs locally even in uniform films: a narrow "hot" metallic channel occurs along the current direction. This was compared the obtained theoretical results with the experiments taken from literature $[14,15]$ and our own and find a good agreement between calculated and measured quantities.

Observed voltage-induced IMT is the local character of the transition nucleation. The IMT occurs within a narrow "hot" channel along the direction of the current flow, while the remaining sample is in the insulating "cold" phase. It was shown that this feature is an inherent property of the overheating instability in the geometry studied and does not require any additional suggestions about film homogeneity.

In all of these cases the blow-up regimen arises from the emergence of positive feedback between the current growth processes and the heating temperature, that there is a connection between the exit and the entrance of the system.

But in our work, studies have been carried out, when the heating regime of the system can be regulated completely regardless of the results of heating. There can be completely different cases - constant heating, slow mode without blowup, rapid heating with or without blow-up. This is the first work to directly study of such processes. 


\section{EXPERIMENTAL SYSTEM}

The block diagram of the experimental system is shown in Fig. 1. The target under heating is an aluminum rod 140 $\mathrm{mm}$ long with the end face of $10 \times 14 \mathrm{~mm}$. An electric heater is located at the end of the rod. he heating power can vary according to the given law. Ten copper-constantan thermocouples are placed along the rod at the distance of $10 \mathrm{~mm}$ from one another. The first thermocouple measures the temperature of the rod end. The signals from the thermocouples enter the indicator unit, where the temperature distribution in time at the control points is recorded.

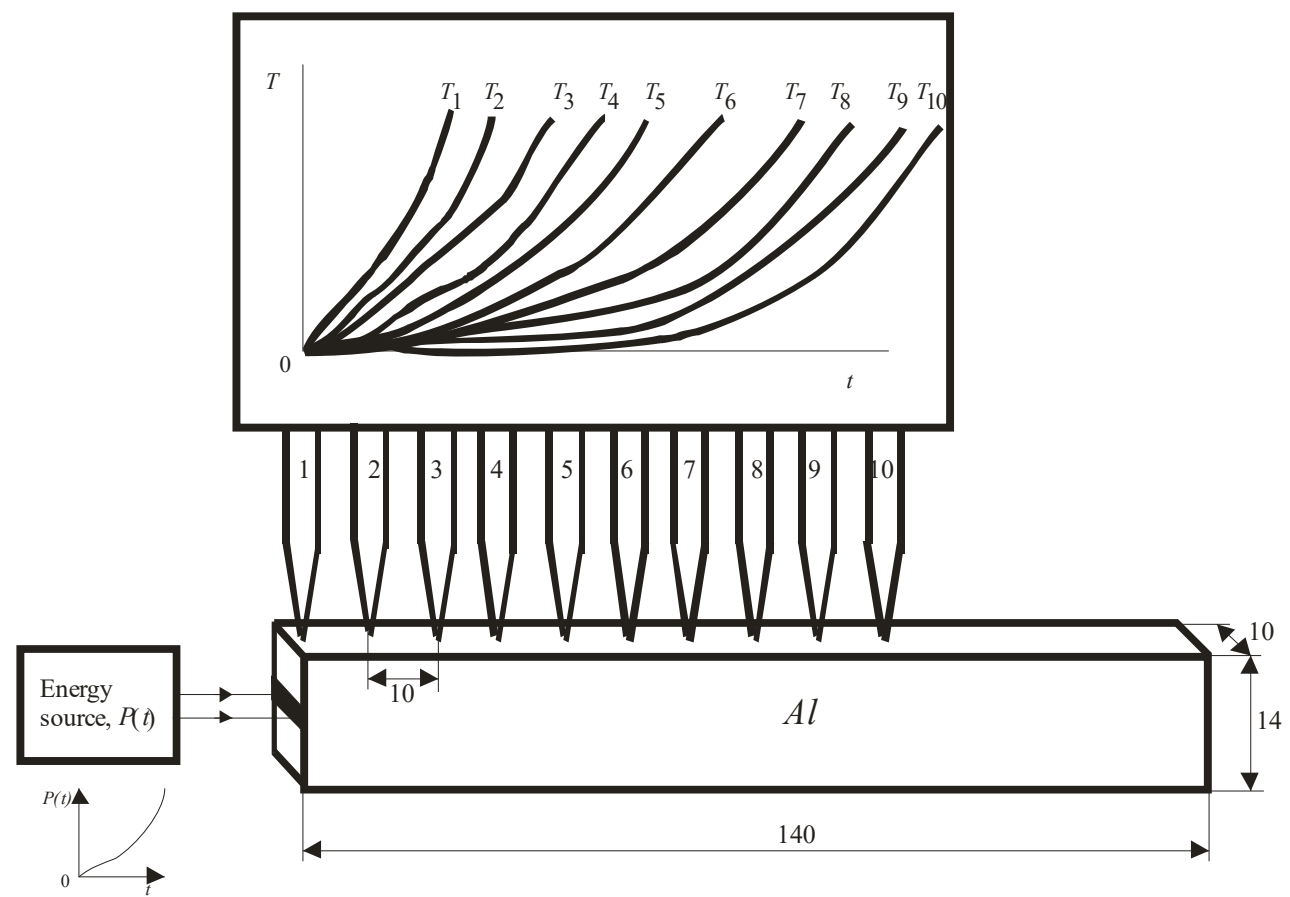

Figure 1. Experimental system

THERMOPHYSICAL PARAMETERS OF THE TARGET

To calculate the thermal conditions, it is necessary to know the target parameters: thermal conductivity $k$, specific heat capacity $c$, density $\rho$, thermal diffusivity $a$, coefficient of heat exchange with the environment $\alpha$. The information about these values, except the heat exchange coefficient, was taken from reference books $[17,18]$. Their values for the sample used in the experiment could differ from the tabulated values. However, this affects the values of the heating temperature, but not the nature of the thermal process.

Thermophysical parameters depend on the temperature. The linear approximation of the data for aluminum gives the following relations:

$$
\begin{gathered}
k(T)=244-0.0486 T, \mathrm{BT} /(\text { м град) } \\
c(T)=878+0.528 T, \text { Дж/(кг гррад) } \\
\rho(T)=2710-0.218 T, \mathrm{\kappa} \Gamma \mathrm{M}^{3} \\
a(T)=10^{-4}-5.18 \cdot 10^{-8} T, \mathrm{~m}^{2} / \mathrm{c} .
\end{gathered}
$$

In these formulas, $T$ is the temperature in Celsius degrees.

The heat exchange coefficient depends on the shape of the object, its location in space (vertical, horizontal), surface treatment and other factors. To determine it an experiment was carried out.

It is known from the theory of heat transfer, that cooling of a heated body occurs according to the exponential law:

$$
T(t)=T_{0} \exp (-t / \tau)
$$

where $\tau=m c / \alpha S$ is the thermal time constant, that is, the time, during which the temperature of the body at its cooling decreases by the factor of $e, S$ is the body surface, $m$ is its mass.

The analysis of the cooling curve (4) shoved the value of the thermal time constant being $380 \mathrm{~s}$, the value of the heat exchange coefficient $\alpha=14 \mathrm{~W} /\left(\mathrm{m}^{2} \cdot \operatorname{deg}\right)$ at the temperature of $20^{\circ} \mathrm{C}$, and the temperature dependence $\alpha(T)=$ $12+0.0136 T, \mathrm{~W} /\left(\mathrm{m}^{2} \cdot \mathrm{deg}\right)$.

\section{THEORETICAL DESCRIPTION OF THE TARGET HEATING PROCESS}

The thermal conductivity equation for the rod was used to describe the thermal processes in the target. The dependences of the thermophysical parameters on the temperature and heat removal into the environment from the lateral surface by convection and thermal radiation were taken into account. As long as the area of the ends is much 
smaller than that of the lateral surface, heat removal from them can be ignored. In the presence of internal heat sources, the heat conduction equation has the following form [19]:

$$
\frac{\partial^{2} T(z, t)}{\partial z^{2}}-\frac{1}{a(T)} \frac{\partial T(z, t)}{\partial t}+\frac{A}{k(T)}=0
$$

Here $A=\Delta P / \Delta V$ is the volume density of the heat energy transferred from the rod by convection and thermal radiation per unit of time to the environment.

The initial condition is:

$$
T(z, 0)=T_{0},
$$

where $T_{0}$ is the ambient temperature.

The boundary conditions:

$$
T(0, t)=T(t), \quad \frac{\partial T(L, t)}{\partial z}=0
$$

They show that one end of the rod with length $L(z=0)$ gets heated according to the given law $T(t)$, and the heat exchange between the other end $(z=L)$ and the environment is absent.

The power delivered to the environment by convection from the section of the rod with length $\Delta z$ is described by Newton law for thermal processes

$$
\Delta P_{k}=\alpha S\left(T-T_{0}\right)=2 \alpha(d+h)\left(T-T_{0}\right) \Delta z .
$$

Here $S=2(d+h) \Delta z$ is the section surface, $d$ and $h$ are the dimensions of the rod cross-section.

Therefore, for the convective heat exchange

$$
A_{k}=\frac{\Delta P_{k}}{\Delta V}=\frac{2 \alpha(d+h)}{d h}\left(T-T_{0}\right) .
$$

At high heating temperatures, which occur in the blow-up regimes, the thermal radiation of the body should be taken into account. The radiation intensity $I$ is described by Stefan-Boltzmann equation. With the non-zero ambient temperature taken into account, it has the following form:

$$
I=\varepsilon \sigma\left[(T+273)^{4}-\left(T_{0}+273\right)^{4}\right],
$$

where $\varepsilon$ is the absorption coefficient, $\sigma$ is the Stefan-Boltzmann constant, $T$ and $T_{0}$ are the temperature of the body and the environment, respectively, in Celsius degrees.

The power, radiated from the section of the rod with the length $\Delta z$, is

$$
\Delta P_{r}=I S=2(d+h) \varepsilon \sigma\left[(T+273)^{4}-\left(T_{0}+273\right)^{4}\right] \Delta z
$$

Therefore, the volume density of the radiated power

$$
A_{r}=\frac{\Delta P_{r}}{\Delta V}=\frac{2(d+h) \varepsilon \sigma}{d h}\left[(T+273)^{4}-\left(T_{0}+273\right)^{4}\right]
$$

The heat total power transferred to the environment is the sum of the convective and radiated powers:

$$
A=A_{k}+A_{r} .
$$

Substitution of expressions (8) and (9) with the "minus" sign into formula (5) gives the following equation:

$$
\frac{\partial^{2} T}{\partial z^{2}}-\frac{2 \alpha(d+h)}{k d h}\left(T-T_{0}\right)-\frac{2(d+h) \varepsilon \sigma}{k d h}\left[(T+273)^{4}-\left(T_{0}+273\right)^{4}\right]-\frac{1}{a} \frac{\partial T}{\partial t}=0
$$

Equation (10) with the initial condition (6) and boundary conditions (7) was solved for two cases: the blow-up regime $-H S$, and the non-blow-up regime $-L S$.

In the non-blow-up regime the temperature of the rod end varies linearly:

$$
T(t)=5 t+20 .
$$

In the blow-up regime the temperature law is set as hyperbolic:

$$
T(t)=\frac{3 \cdot 10^{8}}{(158-t)^{3.2}} .
$$


The diagrams of these processes are shown in Fig. 2. The heating time is $100 \mathrm{~s}$. The parameters of equations (11) and (12) were chosen, so that in both cases the temperature at the onset of the heating process would be about $20^{\circ}$, and at the end - about $600^{\circ}$.

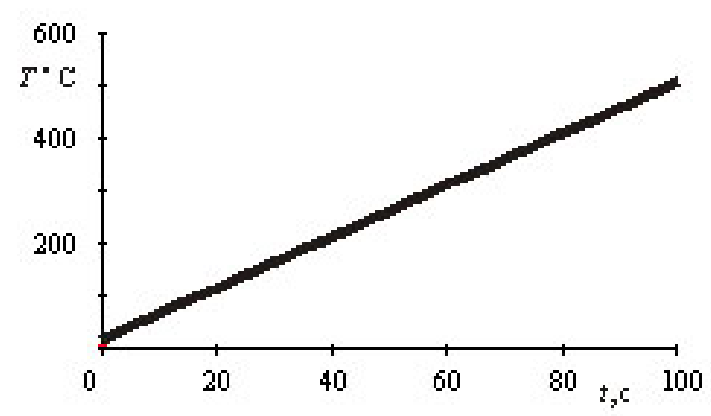

a)

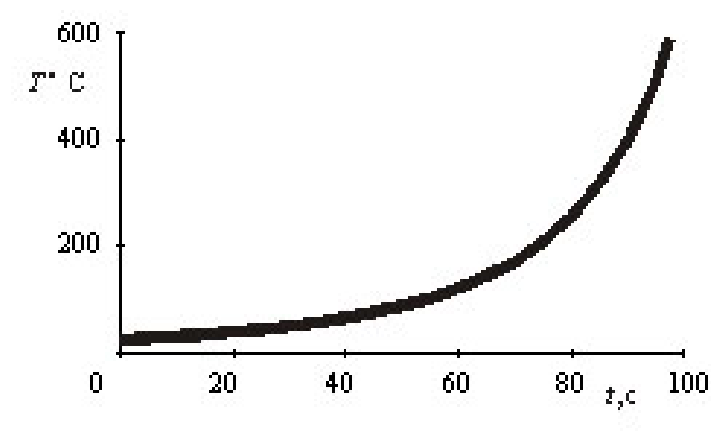

b)

Figure 2. Variation of temperature at the boundary

a) $H S$ (non-blow-up regime), b) $L S$ (blow-up regime)

Fig. 3 shows the temperature distribution in the target at different moments of times. The dots indicate the width of the heat front at half the maximum temperature. In the non-blow-up regime (Fig. 3a) a constant expansion of the heated region occurs. In the blow-up regime (Fig. 3b) the heated area first increases and then decreases.

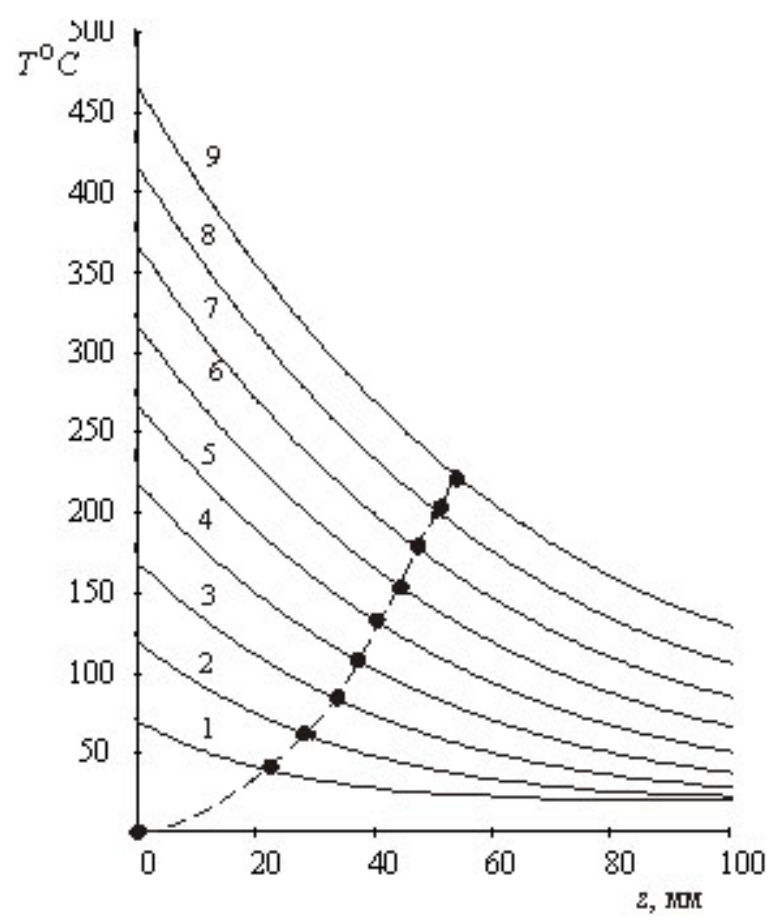

a)

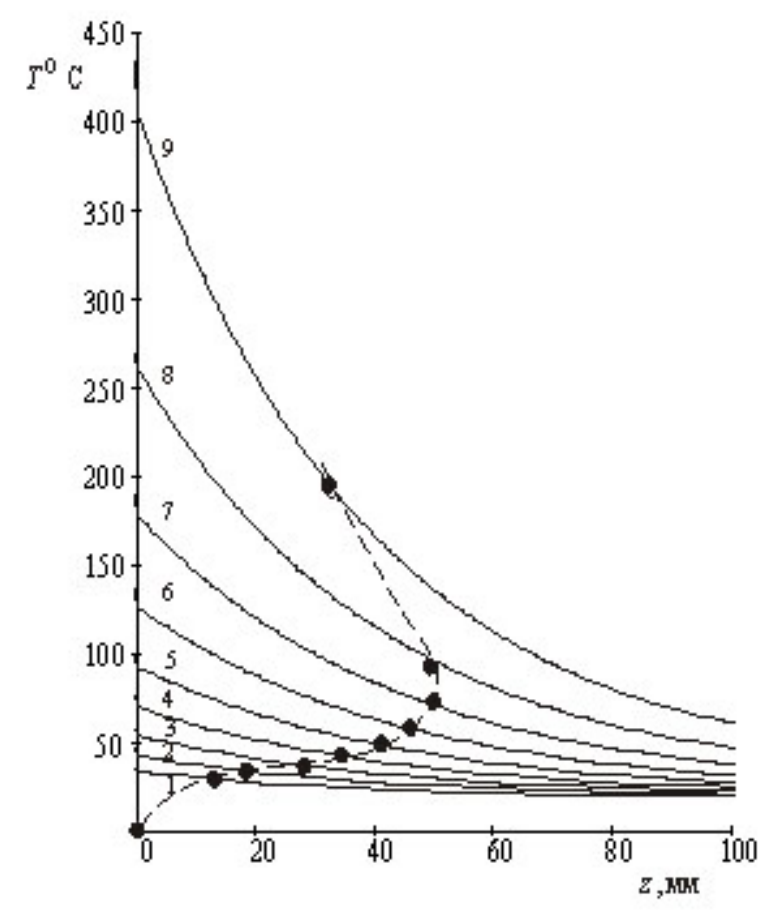

б)

Figure 3. Heat propagation in the target (calculation) a) in the non-blow-up regime, b) in the blow-up regime $1-t=10 \mathrm{~s}, 2-t=20 \mathrm{~s}, 3-t=30 \mathrm{~s}, 4-t=40 \mathrm{~s}, 5-t=50 \mathrm{~s}$, $6-t=60 \mathrm{~s}, 7-t=70 \mathrm{~s}, 8-t=80 \mathrm{~s}, 9-t=90 \mathrm{~s}$.

\section{EXPERIMENT}

In the experiment, the target was heated by passing the electric current through the heater located at the end of the rod. The current varied in time, so that the temperature changed according to the law in the non-blow-up regime (11), and in the blow-up regime (12). The heating duration was $90 \mathrm{~s}$.

Fig. 4 presents the results of the experiment, i.e. the measurements of the temperature distribution in the target. 


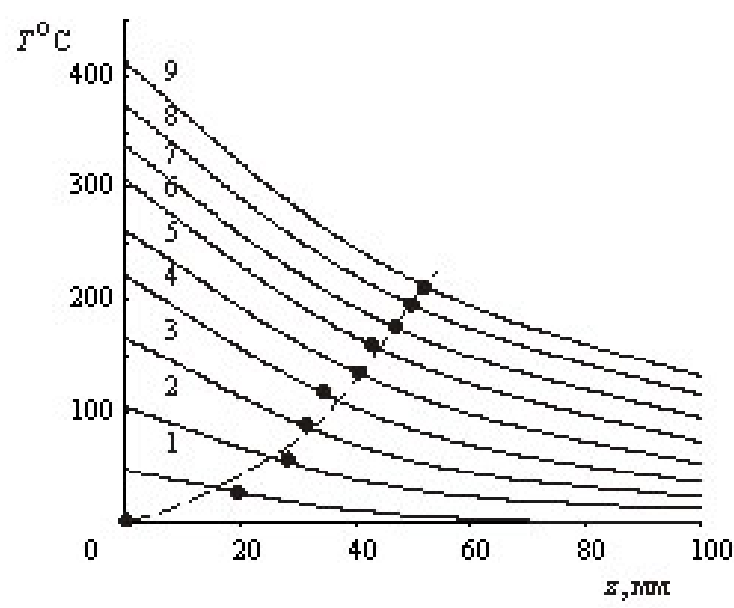

a)

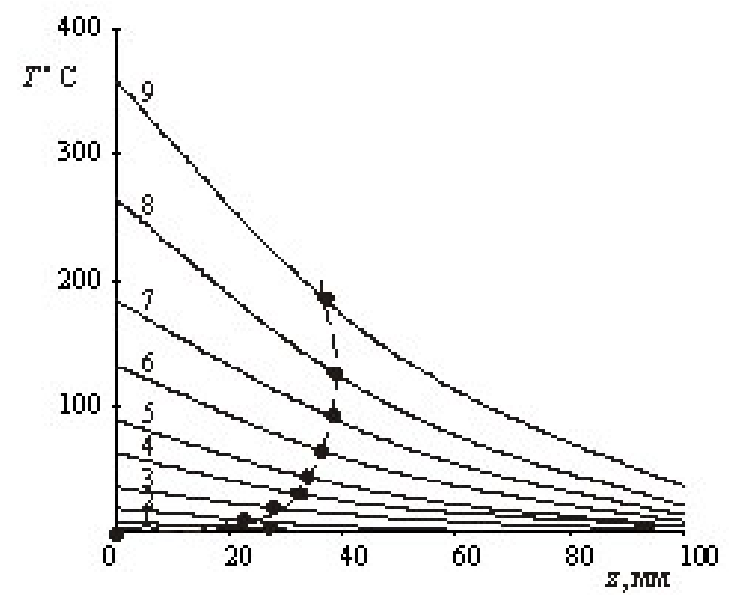

б)

Figure 4. Heat propagation in the target (experiment)

a) in the non-blow-up regime, b) in the blow-up regime

$1-t=10 \mathrm{~s}, 2-t=20 \mathrm{~s}, 3-t=30 \mathrm{~s}, 4-t=40 \mathrm{~s}, 5-t=50 \mathrm{~s}$, $6-t=60 \mathrm{~s}, 7-t=70 \mathrm{~s}, 8-t=80 \mathrm{~s}, 9-t=90 \mathrm{~s}$.

The results of the experiment agree with those of the calculations. In the non-blow-up regime, the heat front moves along the rod, and the size of the heated region reaches the coordinate $z=50 \mathrm{~mm}$. In the blow-up regime, the heat front reaches the coordinate $z=40 \mathrm{~mm}$ and then moves in the opposite direction.

The maximum heating temperature in both cases is approximately the same $\left(350^{\circ}-400^{\circ}\right)$, but the energy input in the blow-up regime is about 2 times lower than that in the non-blow-up regime.

\section{CONCLUSION}

1. The existence of the effect of heat metastable localization in blow-up regimes, predicted by A. A. Samarskii and S. Kurdyumov (Keldysh Institute of Applied Mathematics, RAS, Moscow, Russia), has been experimentally proved.

2. The maximum heating temperatures of the body in both regimes are approximately the same - about $400^{\circ} \mathrm{C}$. But in the blow-up regime the energy input into the body is lower than that in the non-blow-up regime. This is due to the smaller size of the heated area. Thus, the way of strong local heating of the target at a lower input energy is shown. After the end of the process, the size of the heated area increases. But the maximum heating temperature at any point of the medium in the case of the blow-up regime is lower than that in the non-blow-up regime, since the input energy is lower.

3. The effect can be used, when strong local heating of a certain area of the body is required, while the adjacent areas are not to get very hot.

4. The investigations were carried out within the framework of the research work "Energy interaction of electromagnetic radiation with thin conducting fibres", state registration number 0119U002531, at the Department of Quantum Radiophysics of V.N. Karazin Kharkiv National University with participation of the Department of Biophysics and Information Technologies of the National University of Pharmacy.

\section{ORCID IDs}

(D)Nikolay G. Kokodii, https://orcid.org/0000-0003-1325-4563; DStanislav V. Pogorelov, https://orcid.org/0000-0002-0189-8655

\section{REFERENCES}

[1] S.P. Kapitza, S.P. Kurdyumov, G.G. Malinetskiy, Синергетика и прогнозы будущего [Synergetics and Forecasts of the Future], (Nauka, Moscow, 2003), pp. 288. (in Russian)

[2] S.P. Kapitza, in: World population growth as a scaling phenomenon and the population explosion. Climate change and energy policy, edited by L. Rosen, and R. Glasser. (AIP, New York, 1992), pp. 241-248.

[3] S.P. Kapitza, World population growth. A world at the crossroads: new conflicts, new solutions, edited by J. Rotblat. (World Scientific, Singapore, 1994), pp. 198-217, https://doi.org/10.1142/9789814327008_0024.

[4] A.A. Samarsky, N.V. Zmitrenko, S.P. Kurdyumov, and A.P. Mikhailov, Доклады Академии Наук CCCP [Reports of the $\begin{array}{llllll}\text { USSR Academy } & \text { of } & \text { Sciences]. } & \text { 233(6), } & \text { 1344-1347 }\end{array}$ http://www.mathnet.ru/links/0c91838b716a90926704d734c046bb31/dan39241.pdf. (in Russian).

[5] S.P. Kurdyumov, Режимы с обострением [Peaking modes]. (Физматлит, Москва, 2006), pp. 238. (in Russian)

[6] V.A. Kovalev, Сложные системы [Complex systems], 60(3), 50 (2015), pp. 50. (in Russian) 
[7] N.V. Zmitrenko, S.P. Kurdyumov, A.P. Mikhailov, and A.A. Samarskiy, Метастабильная локализация тепла в средах с нелинейной теплопроводностью и условия ее проявления в эксперименте [Metastable localization of heat in media with nonlinear heat conductivity and conditions for its manifestation in experiment], Preprint IPM AH SSSR, 103, 103 (1977), (in Russian)

[8] V.A. Galaktionov, S.P. Kurdyumov, A.P. Mikhailov, and A.A. Samarskii, Действие граничных режимов с обострением на среду с постоянной теплопроводностью [Action of boundary regimes with sharpening on a medium with constant thermal conductivity], Preprint IPM AH SSSR, 28, 76 (1979), (in Russian)

[9] E.N. Knyazeva, and S.P. Kurdyumov, Основания синергетики. Режимы с обострением, самоорганизация, темпомиры [Foundations of Synergetics. Regimes with aggravation, self-organization, tempomir], (Altateya, Sankt Petersburg, 2003), pp. 402. (in Russian)

[10] S.S. Katsnelson, A.M. Orishich, and G.A. Pozdnyakov, Прикладная механика и техническая физика [Applied Mechanics and Technical Physics], 44(5), 23-29 (2003). (in Russian)

[11] A. Zimmers, L. Aigouy, M. Mortier, A. Sharoni, S. Wang, K.G. West, J.G. Ramirez, and I.K. Schuller, Phys. Rev. Lett. 110, 056601 (2013), https://doi.org/10.1103/PhysRevLett.110.056601.

[12] J.G. Ramirez, R. Schmidt, A. Sharoni, M.E. Gomez, I.K. Schuller, and E.J. Patino, Appl. Phys. Lett. 102, 063110 (2013), https://doi.org/10.1063/1.4792052.

[13] J. del Valle, Y. Kalcheim, J. Trastoy, A. Charnukha, D.N. Basov, and I.K. Schuller, Phys. Rev. Appl. 8, 054041 (2017), https://doi.org/10.1103/PhysRevApplied.8.054041.

[14] A.L. Rakhmanov, V.S. Vysotsky, and N.V. Zmitrenko, IEEE Trans. Appl. Supercond. 13, 1942-1945 (2003), https://doi.org/10.1109/TASC.2003.812971.

[15] V. Vysotsky, A. Rakhmanov, and N. Zmitrenko, Thermal stability of Bi-2223 wires, in Research, Fabrication and Applications of Bi-2223 HTS Wires, World Scientific Series in Applications of Superconductivity and Related Phenomena Vol. 1 (World Scientific, Singapore, 2015), pp. 105-122.

[16] V.I. Polozov, S.S. Maklakov, A.L. Rakhmanov, S.A. Maklakov, and V.N. Kisel, Phys. Rev. B, 101, 214310 (2020), https://doi.org/10.1103/PhysRevB.101.214310.

[17] A. Misnar, Теплопроводность твердых тел, жидкостей, газов и их композиций [Thermal conductivity of solids, liquids, gases and their compositions]. (Mir, Moscow, 1968). pp. 464. (in Russian)

[18] I.K. Kikoin, editor, Таблицы физических величин. Справочник [Tables of physical quantities. Handbook]. (Atomizdat, Moscow, Москва, 1976). pp. 1008. (in Russian)

[19] A.V. Lykov, Теория теплопроводности [Heat conduction theory]. (Vysshchsya Shkola, Moscow, 1966). c. 600. (in Russian)

\section{ЛОКАЛІЗАЦІЯ ТЕПЛА В СЕРЕДОВИЩІ В РЕЖИМІ З ЗАГОСТРЕННЯМ \\ М.Г. Кокодій ${ }^{\mathrm{a}, \mathrm{b}}$, С.В. Погорєлов \\ ${ }^{a}$ Харківський національний університет імені В.Н. Каразіна, Харків, Украйна \\ ${ }^{b}$ Начіональний фармацевтичний університет, Харків, Украӥна}

Експериментально доведено існування ефекту метастабільної локалізації тепла в середовищі в режимі нагрівання 3 загостренням. Це режим, при якому густина енергії нагрівання за кінечий проміжок часу росте до нескінченності. Раніше теоретичні дослідження показали, що при цьому можуть створюватись області, температура всередині яких зростає, а розмір залишається постійним або зменшується 3 часом (області локалізації тепла). Області існують, доки відбувається надходження енергії ззовні. Створена установка для експериментального вивчення теплових режимів 3 загостренням в твердому тілі. Об'єктом дослідження був алюмінієвий стрижень 3 нагрівачем на торці. Температура торця стрижня могла змінюватися за заданим законом. Розподіл температури вздовж стрижня вимірювався термопарами. Проведена калібровка установки. Визначена чутливість термопар. Оцінена інерційність процесу нагрівання i охолодження. Зроблено математичний опис теплових процесів, які протікають при проведенні експерименту. Розв'язане нелінійне рівняння теплопровідності для стрижня з урахуванням теплообміну з навколишнім середовищем конвекцією і випромінюванням. Визначено тепловий режим на границі, необхідний для створення теплових структур. Проведені вимірювання розподілу температури в стрижні в режимах з загостренням і без загострення. У режимі з загостренням тепловий фронт (координата точки 3 температурою, в два рази меншою максимальної температури) спочатку поширюється в сторону від місця нагрівання, а потім починає рухатися у зворотний бік, і розмір нагрітої області зменшується. У режимі без загострення розмір нагрітої області весь час збільшується. Ефект передбачалося використовувати в установках для здійснення термоядерного синтезу при нагріванні мішені імпульсами лазерного випромінювання спеціальної форми. Ефект також може бути використаний для локального нагрівання при різанні і зварюванні, коли сусідні області не повинні сильно нагріватися, і інших подібих випадках.

КЛЮЧОВІ СЛОВА: нагрівання, режим із загостренням, теплові структури, експеримент

\section{ЛОКАЛИЗАЦИЯ ТЕПЛА В СРЕДЕ В РЕЖИМЕ С ОБОСТРЕНИЕМ Н.Г. Кокодий ${ }^{\mathrm{a}, \mathrm{b}}$, С.В. Погорелов ${ }^{\mathrm{b}}$

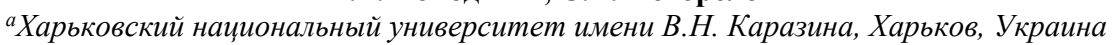 \\ ${ }^{b}$ Национальный фармацевтический университет, Харьков, Украина}

Экспериментально доказано существование эффекта метастабильной локализации тепла в среде в режиме нагрева с обострением. Это режим, при котором мощность энергии нагрева в течение конечного промежутка времени стремится к бесконечности. Ранее теоретические исследования показали, что при этом могут возникать области, внутри которых температура растет, а размер областей остается постоянным или уменьшается с течением времени (области локализации тепла). Области существуют, пока происходит поступление энергии извне. Создана установка для экспериментального изучения тепловых режимов с обострением в твердом теле. Объектом исследования был алюминиевый стержень с нагревателем на торце. Распределение температуры вдоль стержня измерялось термопарами. Температура торца стержня могла меняться по заданному закону. Проведена калибровка установки. Определена чувствительность термопар. Оценена 
инерционность процесса нагрева и остывания. Сделано математическое описание тепловых процессов, протекающих при проведении эксперимента. Решено нелинейное уравнение теплопроводности для стержня с учетом теплообмена с окружающей средой конвекцией и излучением. Определен тепловой режим на границе, необходимый для создания тепловых структур. Проведены измерения распределения температуры в стержне в режимах с обострением и без обострения. В режиме с обострением тепловой фронт (координата точки с температурой, равной половине максимальной температуры) вначале двигается от источника тепла, а затем в обратную сторону, и размер нагреваемой области уменьшается. В режиме без обострения размер нагретой области все время увеличивается. Предсказанный эффект предполагалось использовать в установках для термоядерного синтеза при нагреве мишени импульсами лазерного излучения специальной формы. Эффект может быть также использован для локального нагрева при резании и сварке, когда соседние области не должны сильно нагреваться, и в других подобных случаях.

КЛЮЧЕВЫЕ СЛОВА: нагрев, режим с обострением, тепловые структуры, эксперимент 